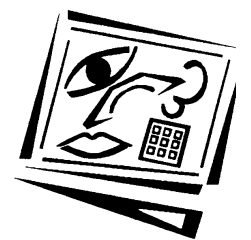

\title{
Students as Web 2.0 authors: Implications for assessment design and conduct
}

\author{
Kathleen Gray, Celia Thompson \\ The University of Melbourne \\ Judithe Sheard, Rosemary Clerehan \\ Monash University \\ Margaret Hamilton \\ RMIT University
}

\begin{abstract}
Students now have at their disposal a range of Web 2.0 authoring forms such as audio and video podcasting, blogging, social bookmarking, social networking, virtual world activities and wiki writing. Many university educators are interested in enabling students to demonstrate their learning by creating content in these forms. However, the design and conduct of assessment for such student-created content is not straightforward. Based upon a review of current literature and examples in the public domain, this paper identifies key challenges for academic assessment that arise from students' use of Web 2.0 authoring forms. We describe and analyse selected cases where academics have set assessable student Web 2.0 activities in a range of fields of study, noting especially the inter-relationship of learning objectives, assessment tasks and marking criteria. We make recommendations for practice, research and understanding to strengthen educational quality and academic integrity in the use of Web 2.0 authoring forms for assessable student learning.
\end{abstract}

\section{Assessment challenges of student Web 2.0 authoring}

University students and staff now have at their disposal a wide range of forms and tools for Web 2.0 authoring, including audio and video podcasting, blogging, social bookmarking, social networking, virtual world activities and wiki writing. Furthermore, there is a growing range of Web 2.0 authoring tools which are designed specifically to suit educational users - both freestanding services such as CiteULike, Edublogs, Serious Games and TeacherTube, and tools incorporated within newer versions of learning management systems such as Blackboard and Moodle. What is more, neither staff nor students need to rely any longer on the online learning infrastructure provided by their educational institutions to give them access to their choice of purpose designed or popular tools. So staff and students together, and students independent of staff, are freer than ever before to use these new Web authoring forms as they choose, to support learning and teaching, inside and outside of academic policies and protocols.

Furthermore, academics are being encouraged to implement Web 2.0 authoring in student learning activities (e.g. Alexander, 2006; Dalsgaard, 2006; Franklin \& van Harmelen, 2007; Richardson, 2006). Student Web 2.0 authoring is thought to improve 
learning in a variety of ways, for example to engage and empower students, to increase peer learning and creative expression, to develop literacy and communication skills, and to inculcate lifelong learning (e.g. Barnes \& Tynan, 2007; Berlanga, Sloep, Brouns, Van Rosmalen, Bitter-Rijpkema \& Koper, 2007; Brown \& Adler, 2008; Godwin, 2007; Lamb \& McLaughlin, 2007; Renner, 2006). Web 2.0 authoring knowledge and skills may be increasingly important to students after graduation too, given that serious uses of Web 2.0 authoring are proliferating in the civic, business, professional and research settings where students may be destined (e.g. ACLS, 2006; Boulos, Maramba \& Wheeler, 2006; Bughin, 2008; Burgess, Foth \& Klaebe, 2006).

Although including students' use of Web 2.0 authoring in academic learning seems to have educational merit, student Web 2.0 authoring is substantially different from traditional forms of assessable student work. The interactivity and social interaction that it encourages cannot be assigned or marked to full effect by using assessment strategies that academics may have used previously, for written reports, essays, examinations or class presentations, for example. In this respect, Web 2.0 activities are different even from earlier forms of online learning activities such as uploading files for assessment or contributing to discussion boards. Furthermore Web 2.0 activities extend the nature not only of individual student work but also of group work. "So the Web 2.0 tension to be managed is one of deciding how to balance the private and the social within the experience of learning.... But it is also a matter of protecting the realistic demands of assessment" (Crook, Fisher, Graber, Harrison, Lewin, Logan et al., 2008, p. 39). This paper therefore seeks to identify and begin to address a critical issue that is currently impeding higher educational innovation with student Web 2.0 authoring, namely the relevant conventions and guidelines for designing and conducting assessment are still underdeveloped.

Improving the quality of assessment activities is a perennial priority for universities (for example, Chalmers, 2007, pp. 89-92). Assessment is said to drive learning in particular ways; as Kirkwood and Price (2008, p. 5) say about online learning, "Assessment influences not only what parts of a course get studied, but also how those parts are studied [....] Appropriately designed assessment that exploits the potential of ICT can change students' approaches to learning". It follows that non-purposeful assessment or inappropriately designed and conducted assessment could have a deleterious effect on student learning and engagement with Web 2.0, and on its appeal and reputation among teaching staff. Setting superficial tasks, requiring ephemeral forms of work for educational credit, accepting work that is without academic rigour or claiming exaggerated learning outcomes from such work, for example, could backfire on those who hope to tap the educational potential of Web 2.0 authoring.

The heightened speed, ubiquity and multiplicity of student content creation that may be enabled by Web 2.0 forms do not automatically create the conditions of transparency and accountability needed to assure good practice in the assessment of student work. The promise of Web 2.0 is that "Learning progress and achievements become visible not only in tests but rather in the learning process documented in portfolios (for example in wikis or weblogs), learning products and social interactions" (Ehlers, 2009, p. 304). However, many educators concede that student Web 2.0 authoring in higher education raises significant challenges for assessment, posing a barrier to further adoption. Examples include Anderson (2007, pp. 54-56); Dron (2006); Elliott (2007); Horizon Report (2008, p. 5); Nillson, Ekloff, and Ottosson (2005); Roberts (2007); Sankey and Huijser (2009); and Selwyn (2007, p. 7). 
Pointers to good practice in assessing student Web 2.0 authoring may be inferred from existing general guides to assessment (such as James, McInnis \& Devlin, 2002; REAP, 2007) and to assessing group learning (such as Isaacs, 2002; Race, 2001), but how to apply them appropriately to the assessment of student Web 2.0 authoring is not always obvious for technical, logistical or pedagogical reasons. The principles of constructive alignment (Biggs, 2003a), for instance, which have been embedded in many higher educational programs, focus on desired levels of understanding and their enactment in target activities with intended learning outcomes. Assessment tasks are worded so that it can be seen to what extent performance meets pre-determined objectives. Responsive assessment of students' Web 2.0 activities by its nature, however, may confound the philosophy underlying this kind of linear approach. It may be that deep engagement in tasks, whether expressed in visual, verbal or embodied language in the fluid and emergent environments of Web 2.0 could fly under - and beyond - the radar of such a system. Even specialised guides that have been developed to support online assessment or e-assessment (e.g. Crisp, 2007; JISC, 2007) may recognise some of the in-principle challenges, but do not give details of how to resolve these in practice in the assessment of student Web 2.0 authoring. As Varvel (2005, p. 4) reminds us, when assessment is online, students may bring books, notes and "the entire Internet, along with friends or even paid helpers. All online assessments essentially become open book in nature. But life itself is open book."

There are also underlying reasons why the assessment of student Web 2.0 authoring is not straightforward. Academics may encounter philosophical arguments against assessing student Web 2.0 authoring, on the grounds that to control or constrain its novel aspects may be contrary to the spirit of Internet use or of adult learning (e.g. Batson, 2007; Hemmi, Bayne \& Land, 2009). Technical or operational suggestions for improving efficiency in the assessment of student Web 2.0 authoring tend to be put forward without reference to any academic quality framework (e.g. Clark, Sampson, Weinberger \& Erkens, 2007; Downes, 2007). A surprising proportion of students may not be familiar with Web 2.0 authoring forms or tools, or may not like using them (e.g. Kennedy, Dalgarno, Gray, Judd, Waycott, Bennett et al., 2007). The scholarly and scientific citation and referencing conventions that student assignments are expected to use are still 'playing catch-up' with regard to many forms of Web 2.0 authoring (Gray, Thompson, Clerehan, Sheard \& Hamilton, 2008). Finally, most official university assessment policies and procedures do not offer guidance on issues of identification, ownership, safety, privacy and recording-keeping of student Web 2.0 work produced for assessment.

The next section of this paper seeks to advance understanding of current practice by bringing together for review and analysis a range of cases in the public domain, where academics have set assessable student Web 2.0 authoring work.

\section{Approaches to assessment of student Web 2.0 authoring}

\section{Method}

Our investigation involved, first, the selection of accounts (peer reviewed where possible) of assessing student Web 2.0 authoring in higher education and second, dissection of their approaches to assessment, in order to contextualise the apparent challenges just described and as groundwork for further research based on primary data collection. The authors systematically searched recent educational conference 
proceedings, journal articles and academic websites in the public domain for accounts of such uses of each Web 2.0 authoring form, using keywords such as "assignment", "grade", "marking" and" rubric". In a few of the Web 2.0 authoring forms where there were many examples to choose from, the authors selected representative cases, based on currency, level of detail, diversity of academic disciplines, variety of software tools and other distinctive features.

We developed a template to describe as concisely and objectively as possible the context, the purpose, the task and the marking system in each case. Then, to the extent made possible by the source document, we analysed the cases, first separately and then as a set, in terms of how they addressed basic criteria for good assessment practice. As a way to relate Web 2.0 authoring assessment in these cases to fundamentals of good assessment practice in higher education generally, we framed this analysis by using criteria from James, McInnis and Devlin (2002). These criteria were selected for our purposes because they are part of a comprehensive and much cited guide endorsed by the Australia Universities Teaching Committee, which is written in a style accessible to educators who might be innovating with student Web 2.0 authoring, while not necessarily being expert in assessment design. We extended these criteria to add the dimension of what might constitute good practice in using Web 2.0 authoring for assessment, that is, ensuring a fit between the affordances of the tool on one hand, and the task and its marking on the other. Table 1 summarises the selected case descriptions; the analytical criteria are used to organise the findings and discussion which follow.

Table 1: Selected cases of assessment of student Web 2.0 authoring in higher education (Sources in Appendix)

\begin{tabular}{|c|c|c|c|}
\hline $\begin{array}{c}\text { Case and } \\
\text { context }\end{array}$ & $\begin{array}{l}\text { Learning outcomes } \\
\text { intended by educators }\end{array}$ & $\begin{array}{c}\text { Tasks required } \\
\text { of students }\end{array}$ & $\begin{array}{l}\text { Grading and mark- } \\
\text { ing information }\end{array}$ \\
\hline $\begin{array}{l}\text { A1 } \\
\text { Audio } \\
\text { Podcasting } \\
\text { (English } \\
\text { language } \\
\text { teacher } \\
\text { training, } \\
\text { level not } \\
\text { known) }\end{array}$ & $\begin{array}{l}\text { To develop critical aware- } \\
\text { ness of e-media to help } \\
\text { select and evaluate appro- } \\
\text { priate teaching resources; } \\
\text { To create and share origi- } \\
\text { nal teaching materials; } \\
\text { To develop critical insight } \\
\text { and greater self aware- } \\
\text { ness, to help in future } \\
\text { lesson planning and } \\
\text { teaching. }\end{array}$ & $\begin{array}{l}\text { Create a three-minute podcast to } \\
\text { teach a grammar point, selecting a } \\
\text { non-fiction text that models its use, } \\
\text { and post on Website; } \\
\text { Listen to a number of these } \\
\text { podcasts and write peer reviews; } \\
\text { Write a self-reflection on } \\
\text { professional learning, setting three } \\
\text { specific goals for professional } \\
\text { development. }\end{array}$ & Not specified. \\
\hline $\begin{array}{l}\text { A2 } \\
\text { Audio } \\
\text { Podcasting } \\
\text { (Modern } \\
\text { literature, } \\
\text { under- } \\
\text { graduate) }\end{array}$ & $\begin{array}{l}\text { To develop digital and } \\
\text { social competencies; } \\
\text { To use tools for } \\
\text { performing and } \\
\text { discussing written } \\
\text { material; } \\
\text { To learn that thinking } \\
\text { about texts is a } \\
\text { collaborative process that } \\
\text { can happen in dialogue. }\end{array}$ & $\begin{array}{l}\text { Create a five-minute podcast based } \\
\text { on selecting and reading a short } \\
\text { passage of the novel under study; } \\
\text { Create another five-minute podcast } \\
\text { discussion of why you chose it, } \\
\text { what details were important, } \\
\text { themes and issues raised, and how } \\
\text { passage related to rest of novel; } \\
\text { Listen to selected podcasts by other } \\
\text { students to prepare for in-class } \\
\text { discussions; } \\
\text { Evaluate one other student's } \\
\text { podcast content as part of writing } \\
\text { assignments. }\end{array}$ & $\begin{array}{l}\text { Students received } \\
\text { written feedback } \\
\text { and grades on both } \\
\text { podcasts; } \\
\text { Some writing } \\
\text { assignments were } \\
\text { marked as in-class } \\
\text { exams. }\end{array}$ \\
\hline
\end{tabular}




\begin{tabular}{|c|c|c|c|}
\hline $\begin{array}{c}\text { Case and } \\
\text { context }\end{array}$ & $\begin{array}{l}\text { Learning outcomes } \\
\text { intended by educators }\end{array}$ & $\begin{array}{l}\text { Tasks required } \\
\text { of students }\end{array}$ & $\begin{array}{l}\text { Grading and mark- } \\
\text { ing information }\end{array}$ \\
\hline \begin{tabular}{|l|} 
B1 \\
Blogging \\
(Profess- \\
ional \\
communic- \\
ation for \\
pharmacists, \\
level not \\
known)
\end{tabular} & $\begin{array}{l}\text { To reflect on course } \\
\text { concepts; To apply them } \\
\text { to the environment } \\
\text { outside the classroom; } \\
\text { To assess communication } \\
\text { performance based on fre- } \\
\text { quency of postings, clarity } \\
\text { of writing, thoughtful- } \\
\text { ness, engagement and } \\
\text { relevance. }\end{array}$ & $\begin{array}{l}\text { Keep a reflective journal with } \\
\text { entries at least twice a week over } \\
\text { one semester. }\end{array}$ & $\begin{array}{l}\text { Based on: } \\
\text { frequency of } \\
\text { postings; clarity in } \\
\text { writing; } \\
\text { thoughtfulness, } \\
\text { engagement and } \\
\text { relevance; } \\
\text { Conducted three } \\
\text { times, at four week } \\
\text { intervals. }\end{array}$ \\
\hline \begin{tabular}{|l|} 
B2 \\
Blogging \\
(Humanities, \\
languages \\
and social \\
sciences, \\
level not \\
known) \\
\end{tabular} & $\begin{array}{l}\text { To enhance learning, } \\
\text { increase student } \\
\text { involvement in and } \\
\text { responsibility for their } \\
\text { learning. }\end{array}$ & $\begin{array}{l}\text { Maintain weekly online learning } \\
\text { logs over the semester in which to } \\
\text { describe prior learning, articles } \\
\text { read and reflections; } \\
\text { Comment on log postings of other } \\
\text { course participants. }\end{array}$ & $\begin{array}{l}\text { Worth } 40 \% \text { of total } \\
\text { grade; Assessed at } \\
\text { the end of semester } \\
\text { Based on: number } \\
\text { of posts, degree of } \\
\text { research, evidence } \\
\text { of consulting other } \\
\text { students' blogs. }\end{array}$ \\
\hline \begin{tabular}{|l|} 
B3 \\
Blogging \\
(Information \\
systems, \\
under- \\
graduate)
\end{tabular} & $\begin{array}{l}\text { To enhance learning, } \\
\text { increase student } \\
\text { involvement in and } \\
\text { responsibility for their } \\
\text { learning. }\end{array}$ & $\begin{array}{l}\text { Maintain weekly online learning } \\
\text { logs over the semester in which to } \\
\text { describe prior learning, articles } \\
\text { read and reflections; } \\
\text { Comment on log postings of other } \\
\text { course participants. }\end{array}$ & $\begin{array}{l}\text { Worth } 24 \% \text { of final } \\
\text { grade. }\end{array}$ \\
\hline $\begin{array}{l}\text { SB1 } \\
\text { Social Book- } \\
\text { marking } \\
\text { (Information } \\
\text { science and } \\
\text { technology, } \\
\text { level not } \\
\text { known) }\end{array}$ & $\begin{array}{l}\text { To be able to create a set } \\
\text { of bookmarks for Web } \\
\text { access; } \\
\text { To be able to share your } \\
\text { bookmarks with anyone } \\
\text { on the Internet. }\end{array}$ & $\begin{array}{l}\text { Establish a bookmarking account; } \\
\text { Create and share a set of } \\
\text { bookmarks relevant to this part of } \\
\text { the course; } \\
\text { Create a taxonomy of your tags } \\
\text { and compare with other students; } \\
\text { In a blog, comment on why and } \\
\text { how the selected and tagged } \\
\text { Websites were chosen; } \\
\text { Review and comment on blog } \\
\text { posts of other students. }\end{array}$ & $\begin{array}{l}\text { Mark for } \\
\text { individual work; } \\
5 \text { blog posts over a } \\
\text { semester, each } \\
\text { worth } 20 \text { points; } \\
\text { Post titled with } \\
\text { name and the } \\
\text { assignment } \\
\text { number - } 5 \text { points; } \\
\text { Use of prescribed } \\
\text { and free tags - } 5 \\
\text { points; } \\
\text { Review of two sites } \\
\text { bookmarked - } 10 \\
\text { points. }\end{array}$ \\
\hline \begin{tabular}{|l|} 
SB2 \\
Social Book- \\
marking \\
(Educational \\
technology, \\
post- \\
graduate)
\end{tabular} & $\begin{array}{l}\text { To learn about Internet } \\
\text { resources and activities } \\
\text { that schools can integrate, } \\
\text { including digital library } \\
\text { resources, Web } 2.0 \\
\text { applications and } \\
\text { collaborative Internet } \\
\text { projects. }\end{array}$ & $\begin{array}{l}\text { Capture, tag and annotate over the } \\
\text { semester a minimum of } 40 \text { links to } \\
\text { items such as lesson plans and } \\
\text { teaching resources; } \\
\text { Share them with the class; } \\
\text { Add other class members to your } \\
\text { personal del.icio.us user network. }\end{array}$ & $\begin{array}{l}\text { One of } 5 \text { Web } 2.0 \\
\text { assignments } \\
\text { during the } \\
\text { semester. }\end{array}$ \\
\hline \begin{tabular}{|l|} 
SB3 \\
Social Book- \\
marking \\
(Educational \\
Internet \\
literacy, \\
post- \\
graduate)
\end{tabular} & $\begin{array}{l}\text { To describe and identify } \\
\text { online collaboration tools, } \\
\text { asynchronous } \\
\text { communication tools and } \\
\text { how they are used in } \\
\text { classrooms. }\end{array}$ & $\begin{array}{l}\text { Create a del.icio.us account; } \\
\text { Find } 10 \text { educational sites; } \\
\text { Add a link to your del.icio.us } \\
\text { account to your wiki; } \\
\text { Add a response to the class wiki } \\
\text { discussion of "Would you advise } \\
\text { your students to create a del.icio.us } \\
\text { account?" }\end{array}$ & $\begin{array}{l}\text { Two of } 37 \\
\text { progressive } \\
\text { assignments worth } \\
\text { a total of } 75 \% \text { of } \\
\text { final grade. }\end{array}$ \\
\hline
\end{tabular}




\begin{tabular}{|c|c|c|c|}
\hline $\begin{array}{c}\text { Case and } \\
\text { context }\end{array}$ & $\begin{array}{l}\text { Learning outcomes } \\
\text { intended by educators }\end{array}$ & $\begin{array}{c}\text { Tasks required } \\
\text { of students }\end{array}$ & $\begin{array}{l}\text { Grading and mark- } \\
\text { ing information }\end{array}$ \\
\hline $\begin{array}{l}\text { SN1 } \\
\text { Social } \\
\text { Networking } \\
\text { (Issues in } \\
\text { electronic } \\
\text { media, } \\
\text { under- } \\
\text { graduate) }\end{array}$ & $\begin{array}{l}\text { To engage with a social } \\
\text { networking site and } \\
\text { reflect on that } \\
\text { engagement critically; } \\
\text { To research social } \\
\text { networking. }\end{array}$ & $\begin{array}{l}\text { Each week for } 6 \text { weeks: } \\
\text { Experience the social networking } \\
\text { site; } \\
\text { Read a relevant paper; } \\
\text { Write a reflections in a blog; } \\
\text { Write a summary; use academic } \\
\text { style (as for an essay); properly } \\
\text { reference any external material } \\
\text { with citations in text and listings in } \\
\text { a bibliography. }\end{array}$ & $\begin{array}{l}\text { Assessed on the } \\
\text { degree to which } \\
\text { entries demonstr- } \\
\text { ate critical engage- } \\
\text { ment with both the } \\
\text { resources read in } \\
\text { the course of resea- } \\
\text { rch and with the } \\
\text { social networking } \\
\text { site itself }\end{array}$ \\
\hline $\begin{array}{l}\text { SN2 } \\
\text { Social } \\
\text { Networking } \\
\text { (Business on } \\
\text { the Internet, } \\
\text { under- } \\
\text { graduate) }\end{array}$ & $\begin{array}{l}\text { To learn about the use of } \\
\text { the Internet for } \\
\text { commercial, educational, } \\
\text { and scientific objectives; } \\
\text { To have a sense of what is } \\
\text { possible with each } \\
\text { technology, what } \\
\text { potential pitfalls exist } \\
\text { along the way, and where } \\
\text { things are likely to go in } \\
\text { the future. }\end{array}$ & $\begin{array}{l}\text { Organise a seminar on The Future } \\
\text { of Social Networking; } \\
\text { Present the technology in enough } \\
\text { depth to give a sense of what is } \\
\text { possible; } \\
\text { Lead student discussion on the } \\
\text { import and potential of the } \\
\text { technology; } \\
\text { Produce a written Web product of } \\
\text { your design on the topic of social } \\
\text { networking, including do } \\
\text { intermediate assignments that } \\
\text { contribute to the project. }\end{array}$ & $\begin{array}{l}\text { Grade based on } \\
\text { oral presentation } \\
\text { and (two-thirds of } \\
\text { the grade) on Web } \\
\text { project; } \\
\text { Formative } \\
\text { assessment of } \\
\text { intermediate } \\
\text { project } \\
\text { assignments. }\end{array}$ \\
\hline $\begin{array}{l}\text { VW1 } \\
\text { Virtual } \\
\text { World } \\
\text { (Behavioural } \\
\text { studies, } \\
\text { under- } \\
\text { graduate) }\end{array}$ & $\begin{array}{l}\text { To introduce the } \\
\text { philosophical and } \\
\text { psychological problems } \\
\text { and understandings of } \\
\text { digital selfhood; } \\
\text { To prepare for the } \\
\text { practise of digital } \\
\text { selfhood. }\end{array}$ & $\begin{array}{l}\text { Create and customise a public } \\
\text { avatar for the virtual world and } \\
\text { write a reflective piece about the } \\
\text { process with reference to theories } \\
\text { of identity; } \\
\text { Collaborate and complete a set task } \\
\text { as part of a virtual world } \\
\text { workgroup; } \\
\text { Create an online presence and } \\
\text { presentation in the virtual world } \\
\text { and / or elsewhere that will be an } \\
\text { extension of your professional } \\
\text { identity as a university graduate; } \\
\text { Regularly participate in the subject } \\
\text { and interact with staff and } \\
\text { students via the Blackboard site. }\end{array}$ & $\begin{array}{l}\text { Staff from several } \\
\text { universities and } \\
\text { disciplines share } \\
\text { teaching and } \\
\text { assessment; } \\
\text { Final mark in the } \\
\text { subject composed } \\
\text { of: } \\
\text { Avatar task: } 20 \% \\
\text { Group project: } 5 \% \\
\text { shared mark plus } \\
15 \% \text { indiv. mark } \\
\text { Regular particip- } \\
\text { ation: } 20 \% \\
\text { Online presence: } \\
\text { (40\% inferred). }\end{array}$ \\
\hline \begin{tabular}{|l} 
VW2 \\
Virtual \\
World \\
(Language \\
and cultural \\
studies, \\
under- \\
graduate)
\end{tabular} & $\begin{array}{l}\text { To learn how to integrate } \\
\text { visual and verbal rhetoric }\end{array}$ & $\begin{array}{l}\text { Create a representation of yourself } \\
\text { in the virtual world: create an } \\
\text { object, upload an image to use as a } \\
\text { texture on the object, write and } \\
\text { post a paper about your future } \\
\text { plans on a Web page, and create a } \\
\text { link to the Web page inside the } \\
\text { object in the virtual world; } \\
\text { Apply your knowledge of icono- } \\
\text { graphy and architectural styles on } \\
\text { campus by creating your own ideal } \\
\text { campus building in the virtual } \\
\text { world and write a piece arguing } \\
\text { why your building is the best; } \\
\text { Attend a social hour in world twice } \\
\text { a week. }\end{array}$ & $\begin{array}{l}\text { Students could } \\
\text { earn extra grades } \\
\text { over and above } \\
\text { their main subject } \\
\text { assignments; } \\
\text { Marks based on } \\
\text { innovative work } \\
\text { and on } \\
\text { "attendance". }\end{array}$ \\
\hline
\end{tabular}




\begin{tabular}{|c|c|c|c|}
\hline $\begin{array}{c}\text { Case and } \\
\text { context }\end{array}$ & $\begin{array}{l}\text { Learning outcomes } \\
\text { intended by educators }\end{array}$ & $\begin{array}{l}\text { Tasks required } \\
\text { of students }\end{array}$ & $\begin{array}{l}\text { Grading and mark- } \\
\text { ing information }\end{array}$ \\
\hline $\begin{array}{l}\text { V1 } \\
\text { Vodcasting } \\
\text { (Media } \\
\text { studies, } \\
\text { under- } \\
\text { graduate) }\end{array}$ & $\begin{array}{l}\text { To see the limitations of } \\
\text { YouTube; } \\
\text { To embrace the culture of } \\
\text { academic research. }\end{array}$ & $\begin{array}{l}\text { Answer generic questions such as } \\
\text { "YouTube is..." and "YouTube } \\
\text { works by..." in video submissions; } \\
\text { Post every assignment online; } \\
\text { Respond to classmates through } \\
\text { posts and other videos; } \\
\text { Choose a thesis topic relating to } \\
\text { YouTube and conduct research } \\
\text { using only the Web site; } \\
\text { In the second half of the syllabus } \\
\text { students as a group decide } \\
\text { whether they want to continue } \\
\text { taping the course or if they want to } \\
\text { have a more conventional class. }\end{array}$ & $\begin{array}{l}\text { Grading of } \\
\text { participation and } \\
\text { posts (9 video plus } \\
9 \text { written): } 40 \% \text {; } \\
\text { Grading on } \\
\text { projects: } 30 \% .\end{array}$ \\
\hline $\begin{array}{l}\text { V2 } \\
\text { Vodcasting } \\
\text { (Human } \\
\text { computer } \\
\text { interaction, } \\
\text { under- } \\
\text { graduate) }\end{array}$ & $\begin{array}{l}\text { To develop a detailed } \\
\text { understanding of the } \\
\text { principles and practices } \\
\text { involved in the creation } \\
\text { and implementation of } \\
\text { user centred interaction } \\
\text { with multimedia products } \\
\text { and systems in business, } \\
\text { entertainment, education } \\
\text { and social environments. }\end{array}$ & $\begin{array}{l}\text { Work with your seminar group to } \\
\text { create a vodcast based on the } \\
\text { seminar presentation of another } \\
\text { group; } \\
\text { Edit down the original } \\
\text { presentation so that it is no longer } \\
\text { than } 10 \text { to } 15 \text { minutes; } \\
\text { Give the presentation a title and } \\
\text { credits; } \\
\text { Insert graphics summarising the } \\
\text { main points; } \\
\text { Upload for other students use to } \\
\text { study for the exam. }\end{array}$ & $\begin{array}{l}\text { One of three assig- } \\
\text { nments; worth 15\% } \\
\text { of overall mark; } \\
\text { Assessment } \\
\text { criteria: Timely } \\
\text { posting (hurdle } \\
\text { requirement); } \\
\text { Capture of video } \\
\text { and audio (5 mks); } \\
\text { Editing, transitions } \\
\text { and sequencing (5 } \\
\text { marks); } \\
\text { Titles, credits and } \\
\text { summary graphics } \\
\text { (5 marks). }\end{array}$ \\
\hline \begin{tabular}{|l|} 
W1 \\
Wiki Writing \\
(New media \\
technologies, \\
under- \\
graduate)
\end{tabular} & $\begin{array}{l}\text { To develop four } \\
\text { capabilities / key } \\
\text { performance indicators } \\
\text { for working in a } \\
\text { networked knowledge } \\
\text { economy: } \\
\text { creativity; collaboration; } \\
\text { criticality; } \\
\text { communication. }\end{array}$ & $\begin{array}{l}\text { Work in pairs to produce a wiki } \\
\text { entry for an existing open resource } \\
\text { wiki on a topic set by the teacher; } \\
\text { Work in pairs to produce a wiki } \\
\text { entry on new media uses (e.g. } \\
\text { blogs; video games); } \\
\text { Work in groups of four to produce } \\
\text { a wiki entry relating to a particular } \\
\text { issue (e.g. intellectual copyright; } \\
\text { management and governance of } \\
\text { the Internet). }\end{array}$ & $\begin{array}{l}25 \% \text { of final grade } \\
\text { for individual } \\
\text { contributions as } \\
\text { recorded in their } \\
\text { editing histories; } \\
75 \% \text { of final mark } \\
\text { given to pair/ } \\
\text { group assessment } \\
\text { based on collab. } \\
\text { abilities over the } \\
\text { project lifecycle as } \\
\text { measured by the } \\
\text { number of contribs } \\
\text { made and the } \\
\text { quality of the } \\
\text { contribs made to } \\
\text { content devt. }\end{array}$ \\
\hline $\begin{array}{l}\text { W2 } \\
\text { Wiki Writing } \\
\text { (Library and } \\
\text { information } \\
\text { studies, } \\
\text { post- } \\
\text { graduate) }\end{array}$ & $\begin{array}{l}\text { To select, organise and } \\
\text { present information tail- } \\
\text { ored to the needs of } \\
\text { specific users; To use } \\
\text { standard bibliographic } \\
\text { conventions appropriat- } \\
\text { ely; To critically evaluate } \\
\text { group decision making } \\
\text { processes and products. }\end{array}$ & $\begin{array}{l}\text { Use a wiki to produce a guide to } \\
\text { online resources in a specific } \\
\text { subject area. }\end{array}$ & $\begin{array}{l}\text { Group marks. } \\
\text { Grades based on } \\
\text { specified learning } \\
\text { objectives. } \\
\text { Marking criteria } \\
\text { include arrange- } \\
\text { ment, navigability, } \\
\text { user friendliness. }\end{array}$ \\
\hline
\end{tabular}




\begin{tabular}{|c|c|c|c|}
\hline $\begin{array}{l}\text { Case and } \\
\text { context }\end{array}$ & $\begin{array}{l}\text { Learning outcomes } \\
\text { intended by educators }\end{array}$ & $\begin{array}{l}\text { Tasks required } \\
\text { of students }\end{array}$ & $\begin{array}{l}\text { Grading and mark- } \\
\text { ing information }\end{array}$ \\
\hline $\begin{array}{l}\text { W3 } \\
\text { Wiki Writing } \\
\text { (Social work, } \\
\text { under- } \\
\text { graduate) }\end{array}$ & $\begin{array}{l}\text { To develop } \\
\text { understanding of subject } \\
\text { content; } \\
\text { To develop graduate } \\
\text { attributes (e.g. use of } \\
\text { online technologies; team } \\
\text { work; critical thinking). }\end{array}$ & $\begin{array}{l}\text { Use a wiki to produce a group } \\
\text { account of a social work practice } \\
\text { theory, for other students in the } \\
\text { course to use; } \\
\text { Individual students draw on this } \\
\text { resource to report on a case study } \\
\text { application of a particular theory. }\end{array}$ & $\begin{array}{l}\text { Shared assessment } \\
\text { of group task; } \\
\text { Individual } \\
\text { assessment of } \\
\text { report. }\end{array}$ \\
\hline
\end{tabular}

This method of investigation did not purport to offer a full critique of any single case of student Web 2.0 authoring assessment in higher education. Description and analysis were limited to what the source publication contained, which could never tell the whole story of a case. We recognise, for example, that in cases where precise instructions as to how students should approach a task or how they would be graded were not found within the published description, this does not mean that they were not made explicit to students in practice; but it does reflect the limitations of the literature in this field.

\section{Findings and discussion}

Our investigation found a paucity of cases which described assessment of student Web 2.0 authoring in higher education in any worthwhile detail, confirming that one barrier to wider assessable use of Web 2.0 authoring may be the lack of examples for academics to draw upon. Interestingly, some good examples were found in other education sectors, for example, Carey's (n.d.) social networking rubric from the middle years of schooling.

We also found great variation in the number of cases available that described assessable uses of different Web 2.0 authoring forms. Assessable uses of blogs and wikis were relatively numerous, with a reasonable number of examples of virtual worlds, while very few such cases of podcasting, social bookmarking or social networking could be found. This suggests that bundling all Web 2.0 authoring forms together, as some of the literature does, may be under emphasising the assessment potential of some forms while over emphasising others.

Among cases of each Web 2.0 authoring form we found that there was quite narrow use of the range of existing software tools, or sometimes tools were not specified. For example, the social bookmarking cases we found mentioned only two of at least six well-known tools. It does not appear that academics are choosing among the variety of Web 2.0 authoring tools available - or the nuances that each one offers for supporting interactivity and facilitating social interaction - to explore new approaches to assessment. Alternatively it is possible that these explorations are unsuccessful and so are not being written up for publication.

To date, Web 2.0 authoring seems to be offered chiefly for optional enrichment or for formative, low stakes assessment. Only a small number of academics, spread across institutions and disciplines, have reported recent experience with student Web 2.0 authoring for medium or high stakes assessment (that is, where tasks earn more than token marks, prompt substantial feedback, can determine student progression and may affect the standing of the course). This indicates that most Web 2.0 authoring in higher education is not assessed and thus, to the extent that assessment drives 
learning, there may be minimal opportunities for it to exert much influence on student learning.

Discussion next turns to how principles of good practice in conventional assessment were reflected in 17 cases. For ease of reference, the tools are identified by their initials (e.g. "A" for audio podcasting, etc)

1. There are explicit learning outcomes, clear criteria and, where possible, statements of the various levels of achievement.

Web 2.0 authoring forms were intended to achieve a variety of different types of outcomes, including learning of discipline based curriculum material (e.g. B1, SN2, VW2) and development of generic skills (e.g. A2, SB1, W1). Sometimes the objective was more interim, to keep students interested in the former types of outcomes (e.g. B2, B3). The language of some outcomes could not be described as measuring achievement in a traditional sense (for instance, "embracing culture", "practising selfhood", "sensing possibility"), rather it suggested a search for innovative ways to describe the learning of new, technologically induced behaviours. Some cases accommodated different levels of assessment, for example B2 had very detailed criteria for five different grade levels.

2. There is a close match between the assessment tasks - in particular, the knowledge and skills these tasks are capable of determining - and the intended learning outcomes.

In cases with discipline based learning objectives, for example where the tasks were a means to the end of improving subject knowledge in pharmacy or social work, tasks were designed with varying degrees of sophistication - in one case, simply keeping a diary of readings, in others providing summaries or interpretations for other learners (e.g. B1, V2). In other cases, where the aim of learning about the Web 2.0 authoring form was a recognised part of building subject knowledge per se, e.g. educational technology and information science, some tasks were performative or skill oriented, i.e. cases where the aim was to learn how to use the Web 2.0 authoring form, and the task was effectively step by step training in using the form (e.g. SB3). There were also a few cases where there was more interplay between Web 2.0 authoring knowledge and skills and the emergence of new subject knowledge in the field, e.g. commerce and journalism; here the tasks were very hands on in their design (e.g. V1, VW2) and sometimes they also had a clear requirement for theory building (e.g. SN2).

3. There is a close match between the assessment tasks - in particular, the knowledge and skills the tasks are capable of determining - and the affordances of the Web 2.0 authoring forms and tools as an adjunct to, or replacement for, other means of assessment.

In several cases, the task started with the use of one form and ended with the use of another (e.g. SB1, SN2), because no single Web 2.0 authoring form had all the affordances required by the assessment task. In a few cases additional collaboration tools were required or optional alongside the Web 2.0 authoring form (e.g. V1, VW1). Almost all (with the exception of V2) had a writing component, and a number did not make use of the tool's potential for multimedia forms of expression (e.g. B1, V1). Only a few mentioned other affordances such as tagging (e.g. SB2) or profiling (e.g. VW1, VW2) and none mentioned "friending", rating, recommending or syndicating. In almost every case, the task involved a sequence of subtasks over a period of weeks, showing an effort to take advantage of the persistence of Web 2.0 authoring content through time, including across student cohorts (e.g. A1, SB1). 
Few cases took advantage of the public accessibility feature of Web 2.0 authoring forms for students to actively engage with those outside their cohort, with the exception of SN1. Some tasks could just as easily have been accomplished by essay submission or class presentation and did not require the use of a Web 2.0 authoring form at all (e.g. SN2).

4. The grades awarded (and other information provided to students on their achievement) make a direct link between the intended learning outcomes and students' actual performance on assessment tasks.

Sometimes marks were given for online participation or "presence" (e.g. V1, VW1), sometimes for process (e.g. B2, VW1, W1) and sometimes for product (e.g. SN1, W2), but it required a lot of inference to make a clear link between the grading system and the learning outcomes stated in most cases. Although many of the cases required group work, marks were most often allocated to the individual student; although peer review and other forms of group assessment featured in most cases, this did not translate into an allocation of marks for this activity, or a peer marking process. In some cases the allocation of marks was clear but encouraged lower orders of cognitive activity (e.g. SB1, V2). Over assessment, when students may be required to write a large number of web page entries - with possible problems ensuing for their learning and teachers' marking - appeared for example in B1 and SB3.

5. The grades awarded (and other information provided to students on their achievement) make a direct link between the intended learning outcomes and students' ability to use the Web 2.0 authoring form and tool in relevant ways.

A few cases set out marking criteria unique to the Web 2.0 authoring form (e.g. VW1, VW2 and W2), but in most cases the criteria for Web 2.0 authoring would be equally applicable to more conventional modes of assessment. Written work was the basis for marking even in cases when writing was not the main mode of expression of a Web 2.0 form, as in podcasting and virtual worlds. Some written pieces were marked as evidence of the student's skill in using the tool (e.g. marks for adding a tag to a bookmark or commenting on another student's blog post). There is some evidence of new approaches afforded by the Web 2.0 authoring forms emerging in the assessment of how often, and occasionally how well, students were using interactivity features or social interaction features: for example, grading students' wiki editing history, the user friendliness of their site design, their tele-presence at a virtual world event or their spoken word performance in a podcast. On the other hand, some cases did not award any marks for using a Web 2.0 form per se (e.g. A1, SN2). Apart from VW2, no marking system gave students credit for innovation, i.e. for discovering and demonstrating affordances that they thought would be suited to the task.

6. The assessment tasks are capable of evidencing the higher-order learning outcomes that characterise higher education.

Many assessment tasks were designed to achieve types of higher-order learning defined as critical thinking, use of language, structuring and argument (Elander, Harrington, Norton, Robinson \& Reddy, 2006, p. 72) or compare/ contrast, explain causes, analyse, relate, apply, theorise, generalise, hypothesise and reflect (Biggs, 2003 b, p. 3). For example, reflective writing appeared in A2, B1, B3 and W2; critical evaluation of subject content and source materials was found in A1, B1, B3, SN1, SN2, W1, W2 and W3; the quality of communication was identified in A1, W1, W2 
and W3; argument was inferred in SN2 and specified in VW2. There was no clear distinction of the expected order of learning according to academic level, i.e. some undergraduate assignments seemed to be more demanding in these respects than some postgraduate ones (e.g. VW1 and VW2 compared with SB2 or W2).

7. The assessment tasks are capable of evidencing the academically appropriate practices (in particular those related to the conventions of acknowledging and attributing sources) that characterise higher education.

Some tasks were class specific, progressive or linked to in class tasks in ways that could help to circumvent inappropriate academic practices (e.g. A2, SB3 and V2). There could be problems using academic conventions for acknowledging and attributing sources in many cases, even where students were reminded of these as in SB2 and SN1. With Web content so readily manipulable, asking students simply to produce text (as in blogging and wiki writing) may inherently encourage repurposing with or without attribution, and so may require more originality checking than asking students to reinterpret it (as in social bookmarking and social networking) or recreate it (as in audio and video podcasting and virtual worlds). But even in A1 it might be difficult to tell how original the spoken word material was, and in A2, how much opinion-gathering from others had contributed to the discussion. The blogs described highlight the need for assignments to be explicit about the extent to which an individual's blog can draw on prior, wiki like collaboration with others, and whether and how to acknowledge sources both academic and non-scholarly. The cases that used a learning management system (V2 and W3) would give teachers more capacity than other tools to authenticate student identities, but a few cases further illustrate how the definition of academically appropriate identity practices may need to be extended - e.g. offering students a choice as to whether they would be seen online or not (V1) and advising students about the significance of presenting professional and personal identities online (VW2).

\section{Conclusions}

The findings from our investigation of 17 cases point to the need for further research and development in an area where innovation in academic practice is being actively encouraged at the same time as the challenges to innovation may be difficult for an individual teacher to resolve. This study has key messages for teachers, academic support staff and policymakers wishing to implement Web 2.0 authoring as part of the assessment of student learning in higher education.

The introductory nature of the assignments in many of the cases in this study suggests there are still many students who, contrary to popular assumptions about the Net Generation, are not "savvy" with the tools and need practice and support even to begin to use them. If students are required to concentrate on learning the basics of a tool but are not then led further into using it in more complex ways to support progressively deeper learning in a field of study, higher education is not well served.

It may be that some Web 2.0 authoring forms are essentially unappealing or intractable for use in assessing student learning. Some Web 2.0 authoring forms might be better thought of not as learning activities, but as learning aids (e.g. social bookmarking) or learning environments (e.g. virtual worlds) which potentiate learning, but do not necessarily cause it to happen. Typically, the design and conduct of traditional 
assessment does not focus on the ways that students choose to use the aids or the environments that the university provides to support it, such as reference management software or wireless networks (unless to induct learners or to remediate poor performance). Perhaps it is preferable, therefore, to conceive of, promote and evaluate certain Web 2.0 authoring tools and forms as learning infrastructure rather than as learning design.

Several cases in this study clearly intended that the Web 2.0 content created by students would form a knowledge base or learning resource for future students, in keeping with Collis and Moonen's (2005, p. 7) "contributing student approach". To make this effective demands redesign of tasks and careful selection of tools, so that students are not being asked to go online just to produce or reproduce content in traditional academic assignment form. We were unable to find examples where students were assessed meaningfully on how they were able to exploit and reflect on a range of Web 2.0 affordances (for example the use of ratings, syndication or tag clouds) for engaging with the continuum of past, present and future activity, with others both known and unknown to them.

The openness of the social Web is an untapped feature in most of the cases we studied. Measuring individual contributions to group activities in any kind of assignment can be a difficult exercise which may appear to reflect unintended bias or personal value judgements on the part of a closed group of assessors. Web 2.0 authoring affords a more open environment in which to conduct such assessment although it appears to be rarely used in this way, possibly because many academics would find this too risky as a way to add rigour to assessment practices. Another possibility not seen in the cases we studied is the facility for student Web 2.0 authoring to be done in the form of contributions to larger, ongoing groups on the web, for example asking a student to add to or create a Wikipedia entry. This may usefully move assessment closer to taking advantage of third-party critique or external moderation, however it may also require much more effort from academics, in coaching students to become discriminating members of the unbounded group of informal learners whose online activities are variously characterised as the global brain or the ignorance of crowds.

To become an accepted and respected part of learning and teaching in higher education, the assessment of student Web 2.0 authoring must be able meet expectations of good practice in assessment generally. The design and conduct of assessment should make it clear how Web 2.0 authoring integrates with other elements and forms of assessment; is linked to specified learning objectives; makes it possible to produce evidence of desired learning outcomes; is supported by adequate instructions and marking rubrics; encourages academic honesty and respects the rights of all authors; provides explanatory and diagnostic feedback; enables peer review and moderation of marking; and can be externally evaluated for purposes of curriculum accreditation and recognition of prior learning. Information gleaned from the cases analysed here indicates that much Web 2.0 assessment practice may still fall short of achieving these expectations.

Moreover, the published literature about student Web 2.0 authoring indicates a general lack of theoretical warrant for the innovative aspects of these practices. There is need to initiate pedagogically driven research into learning and teaching in this area and to apply the evidence it produces. We propose that this needs to be both bottom up and top down: that is, that the theoretical foundations of assessment need to be 
reconceptualised - though possibly still drawing on existing frameworks, such as we have done in this paper - at the same time as intensive examination of current and emergent practice is conducted. (Wyatt-Smith and Kimber, 2008, offer an example of such an enterprise in secondary education.)

Proposals to reform university assessment in a web-influenced world are emerging, for instance Hughes (2008) and Reeves (2006). While there are a number of frameworks upon which one might draw, one promising foundation for assessment research and development may be Wenger's (2006) theory of education as the management of a trajectory of personal identity formation, which occurs through modes of belonging in social systems at many levels of scale. This will require considerable reflection and reformulation, but such thinking may ultimately provide academics with a stronger rationale for designing and conducting assessment of student Web 2.0 authoring - as and when appropriate to a field, level and context of learning. It would be foolish to suggest that the assessment of student Web 2.0 authoring should totally replace other assessment strategies; it is important to consider that it offers some valuable new assessment options.

Advancing the assessment of student Web 2.0 authoring requires a degree of collegial consensus and a level of academic peer review that are not yet in place. Attempts at assessing student Web 2.0 authoring in higher education may founder if they merely replicate existing practices in new forms. Suggestions for using specific Web 2.0 authoring forms innovatively for assessment purposes are scattered too widely across refereed and ephemeral literature, and may be tied too closely to an individual educator's style or experience, to be helpful to an academic community or institution trying to achieve system-wide improvements. A project currently in progress (refer to http: / / www.groups.edna.edu.au/course/view.php?id=2146) aims to address this situation by sharing academics' approaches to educational effectiveness and principled conduct in this area of assessment.

\section{Appendix: Case study sources}

[B1] Bouldin, A., Holmes, E. \& Fortenberry, M. (2006). "Blogging" about course concepts: Using technology for reflective journaling in a communication class. American Journal of Pharmaceutical Education, 70(4), 1-8. [viewed 28 Nov 2008, verified 21 Feb 2010]. http: / / http: / / www.ncbi.nlm.nih.gov/ pmc/articles/PMC1636988/

[B2] Jones, M. \& Magill, K. (2002/2003). Ed-blogs: The use of Weblogs in learning and assessment. University of Wolverhampton. http:/ / hdl.handle.net/2436/5397 [viewed 28 Nov 2008, verified 21 Feb 2010].

[B3] Du, H. \& Wagner, C. (2005). Learning with weblogs: An empirical investigation. In Proceedings of the 38th Hawaii International Conference on System Sciences, 1(72).

[P1] Thompson, L. (2007). Podcasting: The ultimate learning experience and authentic assessment. In ICT: Providing choices for learners and teaching. Proceedings ascilite Singapore 2007. http: / / www.ascilite.org.au / conferences / singapore07/ procs/thompson-poster.pdf

[P2] Evans, L. (2006). Using student podcasts in literature classes. [viewed 28 March 2008, verified 21 Feb 2010]. http:/ / www.academiccommons.org/ctfl/vignette/using-studentpodcasts-in-literature-classes

[SB1] Camplese, C. (2006). Social bookmarking. http: / / camplesegroup.com/blog/?page_id=316 [viewed 28 Nov 2008, verified 21 Feb 2010 at http: / / www.colecamplese.com/teaching/ist-110-blogging-assignments / socialbookmarking/]. 
[SB2] Oliver, K. (2007). Leveraging Web 2.0 in the redesign of a graduate-level technology integration course. TechTrends, 51(5) 55-61.

[SB3] Waide, T. (2008). ED526: Internet literacy for educators. [viewed 1 Dec 2008, verified 21 Feb 2010]. https:/ / internetliteracyforeducators.wikispaces.com/space/showimage/Syllabus.doc

[SN1] Gye, L. (n.d). Network Cultures Social Networking Assignment. [viewed 28 Nov 2008 verified 21 Feb 2010]. http:// www.swinmc.net/documents/ socialnetworksassignment.doc

[SN2] Broznan, A. (n.d). The future of social networking Where do we go from here? [viewed 28 Nov 2008, verified 21 Feb 2010]. http:/ / www.stanford.edu/ abronzan/cs73n/future.html

[V1a] Juhasz, A. (2008). Learning from YouTube. http:/ / au.youtube.com/ user/MediaPraxisme [viewed 1 Dec 2008, verified 21 Feb 2010].

[V1b] Powers, E. (2007). YouTube studies. Inside Higher Ed, 6 September. [viewed 1 Dec 2008, verified 21 Feb 2010]. http:/ / insidehighered.com/news / 2007/ 09/06/ youtube

[V2] Morgan, M. (2008). FIT2016 Human computer interaction for multimedia: Unit guide semester 2 2008. http: / / infotech.monash.edu.au/ units/archive/2008/ s2 / fit2016.pdf [viewed 1 Dec 2008, verified 21 Feb 2010].

[VW1] Collins, F. (2008). Digital selves: Preparing graduates for the virtual workplace. In Proceedings of ED-MEDIA 2008: World Conference on Educational Multimedia, Hypermedia and Telecommunications, 5853-5858, Vienna, Austria.

[VW2] Traphagan, T. (2007). Evaluation of a pilot use of Second Life in an English course 20062007. Division of Instructional Innovation and Assessment, University of Texas at Austin. http: / / www.utexas.edu/academic/mec/publication/pdf/fulltext/SecondLife.pdf [viewed 21 Nov 2008, verified 21 Feb 2010].

[W1] Bruns, A. \& Humphreys. S. (2007). Building collaborative capacities in learners: The M/Cyclopedia project revisited. In Proceedings of the International Symposium on Wikis, Montreal. [viewed 24 Feb 2008]. http:/ / eprints.qut.edu.au/archive/00010518/

[W2] Elgort, I. (2007). Using wikis as a learning tool in higher education. In ICT: Providing choices for learners and learning. Proceedings ascilite Singapore 2007. http: / / www.ascilite.org.au/conferences/ singapore07/ procs/elgort.pdf

[W3] Jones, P. (2007). When a wiki is the way: Exploring the use of a wiki in a constructively aligned learning design. In ICT: Providing choices for learners and learning. Proceedings ascilite Singapore 2007. http:/ / www.ascilite.org.au/conferences/ singapore07/ procs/jones-p.pdf

\section{References}

ACLS (American Council of Learned Societies) (2006). Our Cultural Commonwealth: The report of the ACLS Commission on Cyberinfrastructure for the Humanities and Social Sciences. American Council of Learned Societies. [viewed 1 Apr 2008, verified 21 Feb 2010] http:/ / www.acls.org/ cyberinfrastructure/OurCulturalCommonwealth.pdf

Alexander, B. (2006). Web 2.0: A New wave of innovation for teaching and learning? EDUCAUSE Review, 41(2), 32-44. [viewed 1 April 2008]. http: / connect.educause.edu/ Library / EDUCAUSE+Review/Web20ANewWaveofInnovation/ 40615

Amitay, E., Yogev, S. \& Yom-Tov, E. (2007). Serial sharers: Detecting split identities of web authors. In Proceedings of ACM SIGIR Workshop on Plagiarism Analysis, Authorship Identification, and Near-Duplicate Detection (PAN), Amsterdam, Netherlands. [viewed 1 Apr 2008, verified 21 Feb 2010]. http:/ / einat.Webir.org/SIGIR_PAN_workshop_2007.pdf

Anderson, P. (2007). What is Web 2.0? Ideas, technologies and implications for education. JISC Technology \& Standards Watch, February. [viewed 1 Apr 2008, verified 21 Feb 2010]. http:/ / www.jisc.ac.uk/media/ documents/techwatch/tsw0701b.pdf 
Barnes, C. \& Tynan, B. (2007). The adventures of Miranda in the brave new world: Learning in a Web 2.0 millennium. ALT-Journal, 15(3), 189-200. [verified 21 Feb 2010] http:/ / repository.alt.ac.uk/724/

Batson, T. (2007). The ePortfolio hijacked. Campus Technology, 12 December. [viewed 1 Apr 2008, verified 21 Feb 2010]. http:/ / www.campustechnology.com/articles/56617/

Berlanga, A., Sloep, P., Brouns, F., Van Rosmalen, P., Bitter-Rijpkema, M. \& Koper, R. (2007). Functionality for learning networks: Lessons learned from social web applications. Paper presented at e-Portfolio Conference, October 17-19, in Maastricht, Netherlands. http: / / hdl.handle.net/1820/1011 [viewed 1 Apr 2008, verified 21 Feb 2010].

Biggs, J. (2003a). Teaching for quality learning at university: What the student does. 2nd Edition. Buckingham: Society for Research into Higher Education: Open University Press.

Biggs, J. (2003b). Aligning teaching and assessment to course objectives. Paper presented at ICHEd Conference: Teaching and Learning in Higher Education: New Trends and Innovations, April 13-17, in University of Aveiro, Portugal. [viewed 1 Apr 2008, verified 21 Feb 2010]. http:/ / event.ua.pt/iched/main/invcom/p182.pdf

Boulos, M., Maramba, I. \& Wheeler, S. (2006). Wikis, blogs and podcasts: A new generation of web-based tools for virtual collaborative clinical practice and education. BMC Medical Education, 6(41). http: / / www.biomedcentral.com/ content/ pdf/1472-6920-6-41.pdf [viewed 1 Apr 2008, verified 21 Feb 2010].

Brown, J. \& Adler, R. (2008). Minds on fire: Open education, the long tail, and learning 2.0. EDUCAUSE Review, 43(1), 16-32. http:/ / www.educause.edu/ir/library/pdf/ERM0811.pdf

Bughin, J. (2008). The rise of enterprise 2.0. Direct, Data and Digital Marketing Practice, 9(3), 251259.

Burgess, J., Foth, M. \& Klaebe, H. (2006). Everyday creativity as civic engagement: A cultural citizenship view of new media. In Proceedings Communications Policy $\mathcal{E}$ Research Forum, Sydney, Australia. http:/ / eprints.qut.edu.au/archive/00005056/01/5056_1.pdf

Carey, G. (n.d). Gleeson Year 9 Assignments. https: / /gleeson9itc.pbwiki.com/ Assignments [viewed 20 Nov 2008, verified 21 Feb 2010 at http://gleeson9itc.pbworks.com/Assignments]

Chalmers, D. (2007). A review of Australian and international quality systems and indicators of learning and teaching. Chippendale, NSW: Carrick Institute for Learning and Teaching in Higher Education. [verified 21 Feb 2010] http:/ / www.altc.edu.au/resource-reviewindicators-teaching-learning-2007

Clark, D., Sampson, V., Weinberger, A. \& Erkens. G. (2007). Analytic frameworks for assessing dialogic argumentation in online learning environments. Educational Psychology Review, 19(3), 343-74.

Collis, B. \& Moonen, J. (2005). An on-going journey: Technology as a learning workbench. University of Twente, Enschede, The Netherlands. http: / / www.bettycollisjefmoonen.nl/ rb.htm

Crisp, G. (2007). The e-Assessment Handbook. London: Continuum.

Crook, C., Fisher, T., Graber, R., Harrison, C., Lewin, C., Logan, C., Luckin, R., Oliver, M. \& Sharples, M. (2008). Web 2.0 technologies for learning: The current landscape-opportunities, challenges and tensions. BECTA Research Report. [viewed 1 Feb 2010].

http: / / partners.becta.org.uk/ uploaddir/downloads/page_documents/research/Web2_technologies_learning.pdf

Dalsgaard, C. (2006). Social software: E-learning beyond learning management systems. European Journal of Open, Distance and E-Learning, 2. http: / / www.eurodl.org/materials / contrib / 2006/Christian_Dalsgaard.htm 
Darbyshire, P. \& Burgess, S. (2006). Strategies for dealing with plagiarism and the web in higher education. Journal of Business Systems, Governance and Ethics, 1(4), 27-39. http:/ / www.jbsge.vu.edu.au/issues/vol01no4/Darbyshire-Burgess.pdf

Downes, S. (2007). Open source assessment. Message posted to Half an Hour (blog). http: / / halfanhour.blogspot.com/2007/06/ open-source-assessment.html [viewed 12 Dec 2008, verified 20 Feb 2010].

Dron, J. (2006). The pleasures and perils of social software. In Proceedings of the Higher Education Academy Information and Computer Sciences 7th Annual Conference, 127-131. Dublin, Ireland. [viewed 1 Apr 2008, verified 21 Feb 2010]. http:/ / www.ics.heacademy.ac.uk/ Events/ HEADublin2006_V2/papers/Jon\%20Dron\%2024.pdf

Ehlers, U. (2009). Web 2.0 - e-learning 2.0 - quality 2.0? Quality for new learning cultures. Quality Assurance in Education, 17(3), 296-314.

Elander, J., Harrington, K., Norton, L., Robinson, H. \& Reddy, P. (2006). Complex skills and academic writing: A review of evidence about the types of learning required to meet core assessment criteria. Assessment E Evaluation in Higher Education, 31(1), 71-90.

Elliott, B. (2007). E-assessment: What is Web 2.0? Glasgow: Scottish Qualifications Authority. http:/ / www.sqa.org.uk/sqa/22941.html [viewed 1 Apr 2008, verified 21 Feb 2010].

Franklin, T. \& van Harmelen, M. (2007). Web 2.0 for content for learning and teaching in higher education. JISC Report. [viewed 1 Apr 2008, verified 21 Feb 2010]. http: / / www.jisc.ac.uk/media/ documents / programmes / digitalrepositories / Web2-contentlearning-and-teaching.pdf

Godwin, P. (2007). The Web 2.0 challenge to information literacy. Paper presented at Inforum 2007: 13th Conference on Professional Information Resources, May 22-24, Prague. [viewed 1 Apr 2008, verified 21 Feb 2010]. http: / / www.inforum.cz / pdf/ 2007/ godwin-peter.pdf

Gray, K., Thompson, C., Clerehan, R., Sheard, J. \& Hamilton, M. (2008). Web 2.0 authorship: Issues of referencing and citation for academic integrity. The Internet and Higher Education, $11(2), 112-118$.

Hemmi, A., Bayne, S. \& Land, R. (2009). The appropriation and repurposing of social technologies in higher education. Journal of Computer Assisted Learning, 25(1), 19-30.

Horizon Report (2008). Stanford, California, USA: New Media Consortium / EDUCAUSE Learning Initiative. http: / / www.nmc.org/pdf/2008-Horizon-Report.pdf

Hughes, J. (2008). Open accreditation - a model. Pontydysgu - bridge to learning blog. [viewed 1 Apr 2008, verified 21 Feb 2010]. http:/ / www.pontydysgu.org/2008/10/openaccreditation-a-model/

Isaacs, G. (2002). Assessing Group Tasks. Brisbane: University of Queensland Teaching \& Educational Development Institute. [viewed Apr 2008, verified 21 Feb 2010]. http: / / www.tedi.uq.edu.au/downloads/T\&L_Assess_group_tasks.pdf

James, R., McInnis, C. \& Devlin, M. (2002). Assessing Learning in Australian Universities: Ideas, Strategies and Resources for Quality in Assessment: Five Practical Guides. The University of Melbourne Centre for the Study of Higher Education / Australian Universities Teaching Committee. http:/ / www.cshe.unimelb.edu.au/assessinglearning/03/ and http:// www.cshe.unimelb.edu.au/assessinglearning/06/ [viewed 1 Apr 2008, verified 21 Feb 2010].

JISC (2007). Effective practice with e-assessment: An overview of technologies, policies and practice in further and higher education. UK: HEFCE. [viewed 1 Apr 2008, verified 21 Feb 2010]. http: / / www.jisc.ac.uk/media/ documents/themes/ elearning/effpraceassess.pdf 
Kennedy, G., Dalgarno, B., Gray, K., Judd, T., Waycott, J., Bennett, S., Maton, K., Krause, K. L., Bishop, A., Chang, R. \& Churchward, A. (2007). The Net Generation are not big users of Web 2.0 technologies: preliminary findings. In ICT: Providing choices for learners and learning. Proceedings ascilite Singapore 2007. http: / / www.ascilite.org.au/conferences/ singapore07/procs/kennedy.pdf

Kirkwood, A. \& Price, L. (2008). Assessment and student learning: a fundamental relationship and the role of information and communication technologies. Open Learning: The Journal of Open and Distance Learning, 23(1), 5-16.

Lamb, K. \& McLaughlin, C. (2008). e-Assessment 07/ 08: Training and support initiatives. Edinburgh: JISC Regional Support Centres for Scotland. http: / / www.rsc-swscotland.ac.uk/eAssessment/docfiles / e-Assessment_Initiatives_2007-08.pdf

Martin, A. (2005). The landscape of digital literacy. DigEuLit Project. http: / / www.digeulit.ec/docs / public.asp [viewed 1 Apr 2008, not found 21 Feb 2010, see http:/ / www.elearningeuropa.info/directory/index.php?page=doc\&doc_id=6007\&doclng=6]

Nillson, L., Eklof, A. \& Ottosson, T. (2005). What's so original? The discourse on education and dishonesty in the wake of a technological revolution. Paper presented at The 11th Biennial Conference of the European Association for Research on Learning and Instruction (EARLI), Nicosia, Cyprus. [viewed 1 Apr 2008, verified 21 Feb 2010] http: / / www.distans.hkr.se / ILLWebb / Earli_paper2005_whats_so_original_final.pdf

Race, P. (2001). A briefing on self, peer and group assessment. Assessment Series No. 9. UK: LTSN Generic Centre. http:/ / internt.iha.dk/paedagogik/seminarer/Chris\%20Rust/ ASS009 PhilRace.pdf [viewed 1 Apr 2008, verified 21 Feb 2010 at http: / / www.palatine.ac.uk/ files / 970.pdf]

REAP (ReEngineering Assessment Practices in Scottish Higher Education Project) (2007). Assessment principles: Some possible candidates. [viewed 1 Apr 2008, verified 21 Feb 2010]. http:/ / www.reap.ac.uk/ resourcesPrinciples.html

Reeves, T. (2006). How do you know they are learning? The importance of alignment in higher education. International Journal of Learning Technology, 2(4), 294-309. [verified 21 Feb 2010] http: / / net.educause.edu/ir/library/pdf/ELI08105A.pdf

Renner, W. (2006). E-learning 2.0: New frontier for student empowerment. Paper presented at Edu-Com 2006, 22-24 November, Nong Khai, Thailand. [viewed 1 Apr 2008, verified 21 Feb 2010]. http:/ / blogs.usyd.edu.au/elearning/elearning2.pdf

Richardson, W. (2006). Blogs, wikis, podcasts, and other powerful web tools for classrooms. Thousand Oaks, California, USA: Corwin Press.

Roberts, E. (2007). Transforming digital content into learning. Presentation at The Sixth Annual ECAR/HP Summer Symposium for Higher Education IT Executives, 11-13 June, Boulder, Colorado. http: / / connect.educause.edu/Library / ECAR/TransformingDigitalConten / 45012 [viewed 1 Apr 2008, verified 21 Feb 2010]

Sankey, M. \& Huijser, H. (2009). A 'likely benefit' from aligning Web 2.0 technologies with an institution's learning and teaching agenda. In: 2009 World Conference on E-Learning in Corporate, Government, Healthcare \& Higher Education (E-LEARN 2009), 26-30 Oct 2009, Vancouver, Canada. http: / / eprints.usq.edu.au/6055/

Selwyn, N. (2007). Web 2.0 applications as alternative environments for informal learning - a critical review. Paper presented at the OECD-KERIS Expert Meeting - Session 6 - Alternative learning environments in practice: Using ICT to change impact and outcomes. [viewed $1 \mathrm{Apr}$ 2008, verified 21 Feb 2010]. http:/ / www.oecd.org/ dataoecd / 32/3/39458556.pdf 
Sener, J. (2007). In search of student-generated content in online education. e-mentor, 4(21). [viewed 1 Apr 2008, verified 21 Feb 2010]. http:/ / e-mentor.edu.pl/_xml/wydania/21/467.pdf

Varvel, V. (2005). Honesty in online education. Pointers and Clickers, 6(1), 1-20. [verified 21 Feb 2010] http:/ / www.ion.uillinois.edu/resources/ pointersclickers/2005_01/VarvelCheatPoint2005.pdf

Wenger, E. (2006). Learning for a small planet: A research agenda. [viewed 1 Dec 2008, verified 21 Feb 2010]. http:/ / ewenger.com/ research/LSPfoundingdoc.doc

Wyatt-Smith, C. \& Kimber, K. (2008). Valuing and evaluating student-generated online multimodal texts: Rethinking what counts. English in Education, 39(2), 22-43.

Kathleen Gray, Faculty of Medicine, Dentistry and Health Sciences,

The University of Melbourne. Email: kgray@unimelb.edu.au

Celia Thompson, School of Languages and Linguistics,

The University of Melbourne.

Judithe Sheard, Faculty of Information Technology, Monash University.

Rosemary Clerehan, Faculty of Medicine, Nursing and Health Sciences, Monash University.

Margaret Hamilton, School of Computer Science and Information Technology, RMIT University. 